\title{
Bullying in Elementary Schools: Optimizing the Understanding of Social Perspective and Moral Reasoning through Character Education
}

\author{
Puri Selfi Cholifah \\ Elementary School Teacher Education \\ Universitas Negeri Malang \\ Malang, Indonesia \\ puri.selfi.fip@um.ac.id
}

\begin{abstract}
Bullying is increasingly prevalent in many schools. This is because the understanding of social perspective and moral reasoning is not optimal. Character education is one of the efforts in the moral cultivation of students to increase understanding of the social aspects of children. Therefore it is important to review the implementation of character education that is able to answer these needs. In line with this phenomenon, this paper will discuss (1) bullying in the school environment, (2) understanding of social perspectives and moral reasoning of elementary school age children, (3) character education in elementary schools, and (4) optimization of character education in elementary school in handling bullying.
\end{abstract}

Keywords - character education, bullying, elementary school, social perspective, moral reasoning

\section{INTRODUCTION}

Bullying behavior is increasingly prevalent in the school environment, even victims and perpetrators are also increasingly in the category of elementary school children. Many forms of intimidation that are categorized in bullying include verbal, physical, to continuous isolation. This is an indication that it is important to see this problem as a crucial educational problem and must be resolved immediately.

Education becomes an important path that bridges changes in one's behavior that starts with changing their understanding of themselves in the social environment. Optimization of individuals to become superior individuals can certainly be better with the proportional development between the three aspects, namely affective, psychomotor, and cognitive. Fundamentally, education which is viewed from the psychosocial aspect is an effort to develop human resources in interpersonal relationships in the family or community, because in truth individuals are part of the social environment and humans are social beings.

Positive ties between students and teachers and students become one of the indicators in developing students' social relations patterns with the environment. Syah states that students' positive or negative perceptions of their teachers or friends will affect the social quality of students with their social environment [1]. Furthermore, the existence of a positive bond between students and teachers is a productive way in which the class becomes a space that supports the achievement of students academically and socially [2]. However, in these processes, not everything can work well. Negative patterns, one of which occurs continuously due to bullying, can be a fatal understanding if continued without preventive efforts.

Many facts in the field indicate that cases related to bullying occur in the educational environment. Based on the results of a study conducted by Jensen, as many as one-third of children aged 5-6 years were involved in bullying with $17 \%$ of them being perpetrators and $13 \%$ being victims of bullying. Moreover, in 2013 data showed that as many as $19.6 \%$ of students claimed to have been victims of bullying at school, while related to bullying in cyberspace or electronically stated by $14.8 \%$ of students [3]. Data in Indonesia revealed that as many as a quarter of the cases reported to the Indonesian Child Protection Commission (KPAI) were cases of bullying which became the biggest domination of defeating other cases.

Elementary school-age children should indeed have an understanding of social perspectives because they are related to developmental tasks in childhood. The main characteristics of childhood tasks according to Syah include: 1) having the urge to go out of the house and enter a peer group, 2) physical condition is more likely to play games and physical work, and 3) has a mental urge to enter concepts, logic, and communication [1]. The age characteristics of the child may develop faster towards the characteristics of adolescents with more intense social relationships with children over their age resulting from the construct of peer relationships. The construct is because children aged 7 years to 16 years of age become very dependent on concrete attributes that are inherent, but rather based on psychological descriptors in determining the character of their [4].

Therefore, education has an important role in overcoming negative things in relation to understanding the social perspective of children through character education. Character education is one of the efforts in the moral cultivation of students. Miller stated that character education is a crucial component in the prevention of violence that occurs in schools [5]. In character education, efforts must be made to increase understanding of the social and moral aspects of children. Therefore, it is important to examine all of these components in order to overcome bullying in elementary schools. In line with this exposure, this paper will review (1) bullying in the school environment, (2) understanding of social perspectives and moral reasoning of elementary school age children, (3) character education in elementary schools, and (4) optimization of character education in elementary school in handling bullying. 


\section{BULLYING IN THE SCHOOL ENVIRONMENT}

The definition of bullying is expressed as diverse by many experts, whether surface or in depth. Bullying is defined as an attempt to systematically abuse power [6]. This abuse is closely related to the social hierarchy in the social environment. Furthermore, another definition is expressed by Tattum and Herbert that bullying is a behavior that intentionally aims to hurt or put pressure on others [7]. The intensity of repeatedly or all the time using negative actions is also one of the definitions of bullying [8]. Another definition is bullying is a behavior that is categorized in a continuous or repeated physical, verbal, mental, or social attack carried out by a dominant person or group to someone who has no power with the aim of putting pressure and obtaining satisfaction [9],[10], and [11]. In general, both physical and verbal or mental violence intentionally carried out with the aim of intimidating and seeking satisfaction is categorized as bullying.

It is important for teachers to understand the categories or types of bullying so that they can take special precautions or handling. Bullying actors or bullies have characteristics: (1) more aggressive and harder when compared to other students, (2) confident, popular, dominant, and superior, (3) physically stronger and have more energy, and (4) likes to show off rude behavior [6] and [12]. The victim is a target student of bullying who constantly receives bully behavior from the perpetrator [13]. Characteristics of victims generally have a low assertiveness, lack of confidence, easily restless, physically weaker, quiet, and difficult to socialize [6], [8], and [9]. The third category is witnesses or bystanders. This category is the dominant category because they become a person who does not want to be involved. Some students tend to choose to avoid bullying between the perpetrator and the victim. The characteristics of this category are susceptible to negative things and generally apathetic and the largest representation of groups [11] and [14].

The cause of bullying is rooted in the environmental conditions that shape his personality to be aggressive and unable to control emotions. Factors that influence include internal factors of students, family, and the social environment of students. Student internal factors include high temperament [8], aggressive personality [9], low selfattitude and self-acceptance [15], and biological factors related to serotonin as a controlling attitude and testosterone are associated with an aggressive action [16].

The factors related to social behavior are (1) student popularity, (2) friendship patterns, (3) friendship development stage, and (4) social behavior in groups [9]. Another thing that should be considered is student learning patterns. Children are able to learn from aggressive behavior seen by parents, schools and the media, especially through television [16]. School factors become important when schools fail to provide a situation or climate that is conducive to children's development, both the behavior of teachers or school staff [17]. All of these factors are not only a trigger for bullying behavior but also an iceberg effect that can be negative at any time from bullying. Understanding these factors is important when faced with symptoms that arise and are encountered in student behavior. The main thing that happens is to identify the biggest factor then take an intervention.

\section{UNDERSTANDING SOCIAL PERSPECTIVES AND MORAL REASONING OF ELEMENTARY SCHOOL AGE CHILDREN}

Understanding social perspective is closely related to the condition of one's social cognition. Social cognition is the process of thinking about how other people will think, act, and react [18]. There are two aspects of social cognition that affect a child to establish friendly relationships with others, namely the ability to consider other people and the ability to process social information. The ability to consider other people's perspectives is the ability of someone to see a situation from someone else's point of view. This ability that develops well can enable students to develop good interpersonal relationships as well. Therefore, the social perspective is closely related to individual social competence.

Regarding cognitive development, elementary school-age children still do not think abstractly and tend to do concrete object observations. Even so, the child is able to conclude that people who exhibit certain behaviors also have certain feelings or intentions [18]. When children go through elementary school, children are better able to make complex conclusions about other people's mentality. For example, a child may think that someone who seems happy can be sad. In addition, children tend to be able to realize the feelings of others is a complex feeling about a particular situation. Children also understand that a person may perceive a situation differently from his perception.

Along with understanding social perspectives, moral reasoning is a part that has been developed during the development of children in elementary school age. The existence of a common standard of morality related to right and wrong and other moral aspects certainly affects children's beliefs regarding one's behavior. Before children enter school age children actually have been able to show an emotional response to the distress and suffering of others. Children can feel guilty if they realize that they have disturbed or suffered others. Guilt will arise if you do something wrong or wrong. The ability to empathize appears in the preschool to childhood and adult years. Children tend to increase their desire to empathize with individuals who have not been known or suffer from deprivation. Further according to Carlson that getting older adults will reduce the egocentric nature of the child and become more able to empathize with the feelings or actions of others [19].

The tendency of empathy is related to the development of one's moral reasoning. In accordance with Piaget's moral theory that heteronomous morality children tend to think that rules cannot be changed and violate these rules will automatically get punishment. Piaget in Slavin states that children at that age can generally say immoral acts based on the consequences [15]. It also means that the child will still say a bad behavior based on the negative effects caused even if the culprit is a good person.

Regarding bullying behavior, at this stage, children who are instinctively in the process of social understanding and moral reasoning are vulnerable to negative behaviors that can be inherent in them. The tendency to have empathy or guilt in bullying cases must certainly be more attention and priority so that the planting of positive values becomes important especially in relation to character education. 


\section{CHARACTER EDUCATION IN ELEMENTARY SCHOOL}

Character education is basically a process of internalizing values in an effort to develop the values of children's goodness so that they can manifest in good behavior [20]. Systematic efforts lead to good behavior as an individual optimization. Character education prioritizes moral development in educational institutions in order to achieve character education goals where individuals can grow as positive citizens.

Lickona stressed the importance of the three components of an individual's character, namely moral knowing, moral feeling, and moral action [21]. Moral knowing is related to the cognitive purpose of moral understanding, namely moral awareness, knowing moral values, perspective taking, moral reasoning, decision making, and self-convergence. Moral feeling related to one's feelings for the character which consists of conscience, self-esteem, empathy, loving the good, self-control, and humility. The moral action is related to individual activities or actions that result from the two previous components.

The success of character education depends on three important elements, namely the principles, processes, and practices in learning. The values taught must be integrated into the curriculum so that students are able to understand the purpose of the values and translate them into real action. Character education will not succeed without the support of all school components. Starting from the principal, teachers, parents, the surrounding community, and school residents who will support and create an atmosphere of growth and development of good values. Schools with full implementation feel that behavioral improvement is in line with positive characters compared to those that do not fully implement [22].

Furthermore, character education contributes positively to students' academic achievement not only in the same year but over the next two years [23]. The study shows that character education determines the development of the nation's generation by creating generations that are mentally intelligent, careful, and behave. The importance of character education will be realized if all components of the school understand the meaning of character education, and will be easier to integrate and implement in daily activities or behavior.

\section{OPTIMIZATION OF CHARACTER EDUCATION IN ELEMENTARY SCHOOLS IN HANDLING OF BULLYING}

Understanding social perspectives and moral reasoning is an urgent matter, one of which can be implemented through character education in schools. Furthermore, with the implementation of character education, it is expected to be able to deal with the problem of bullying by taking preventive measures as well as proper handling. Optimization of moral leadership and social behavior should be demonstrated by all aspects so that the role of adults in this case teachers, parents, principals, and the community becomes important.

Optimizing the role of the family becomes important because the parent figure becomes the main and greatest role model for children in understanding moral and social in their immediate environment. Optimization of the school in preventing bullying will have a positive impact on students by doing various creative ways including social activities and improving children's creativity through things that support their potential and talents to be enhanced through a series of positive activities. There are several approaches and methods for optimizing character education in schools, one of them is by integrating values in learning comprehensively. Comprehensive approach encompasses the content or problems related to the overall character [20].

The next effort is to optimize the role of the teacher. Surprisingly, the teacher turns out to be even a bully by accident because he calls his students stupid or makes them afraid of rejection [10]. Therefore, it is important for teachers to understand psychological aspects, related to moral reasoning, social perspectives, and understanding bullying. In this case, the role of university institutions is important in providing lecture materials related to these matters.

Other optimizations are by strengthening the role of all components, in this case, all school residents both students, teachers, staff, principals, and others in developing a positive school culture in the institution. School political policies also play an important role in influencing the implementation of character education [24]. The internalization of values in school policy includes clinical stages which include identification, policy development, implementation, and evaluation [6]. All components must be able to contribute in efforts to identify needs related to character education issues in the school, contribute to policy development, participate actively in policy implementation, and contribute when monitoring and evaluating related policies or programs. Therefore, the actions taken in the settlement of bullying must involve all components, namely teachers, parents, school staff, and stakeholders to assist students in manifesting the positive values that occur in students' lives.

\section{CONCLUSION}

Bullying is generally defined as acts of physical or verbal or mental violence that are intentionally carried out with the aim of intimidating and seeking satisfaction. It is important to immediately follow up on bullying cases that occur in children. That is because instinctively the child is in the process of social understanding and moral reasoning so that the child will become vulnerable to negative behaviors that can be inherent in him. The tendency to behave positively in order to instill moral and social values is carried out through character education which can be done with several efforts. Optimization of character education can be done by optimizing moral leadership and social behavior, optimizing the role of the family, optimizing comprehensive character education, and optimizing the role of teachers

\section{REFERENCE}

[1] M. Syah, Psikologi Pendidikan dengan Pendekatan Baru. Bandung, PT Remaja Rosdakarya. 2010

[2] B. K., Hamre, and R. C. Pianta, "Early teacher-child relationships and the trajectory of children's school outcomes through eighth grade," in Child Development, vol. 72(2), pp. 625-638, 2001, https://www.jstor.org/stable/1132418.

[3] CDC (Centers for Disease Control and Prevention). Understanding School Violences. http://www.cdc.gov/violenceprevention/pdf/school_violence_fact_she et-a.pdf, 2015.

[4] D. R., Shaffer and K. Kipp, Developmental Psychology: Childhood and Adolescence, Eighth Edition. Belmont, CA: Wadsworth. 2010.

[5] T. W. Miller, R. F. Kraus, and L. J. Veltkamp. "Character Education as a Prevention Strategy in School Violence," in The Journal on 
Primary Prevention, vol. 26(5), pp. 455-66, 2015, doi: 10.1007/x10935-0004-x

[6] P. K. Smith, and S. Sharp, The Problem of School Bullying. Dalam Smith, P. K. and Sharp, S. (Eds.), School Bullying: Insight and Perspectives, London: Routledge. 1994. pp. 1-20.

[7] D. Tattum, and G. Herbert, Countering Bullying: Innitiatives by Schools and Local Authorities. Standfordshire, ST: Trentham Books Limited. 1993.

[8] D. Olweus, Bullying at School: What We Know and What We Can Do. Oxford, OX: Blackwell Publisher. 1993.

[9] V. Besag, Bullies and Victims in Schools: a Guide to Understanding and Management. Buckingham, MK: Open University Press. 1989.

[10] K. D. Moore, Effective Instructional Strategies: From Theory to Practice. Thousand Oaks, California: SAGE Publications. 2015. P.80

[11] S. Padget, and C. E. Notar, "Bystanders are the Key to Stopping Bullying." in Universal Journal of Educational Research, vol. 1(2), 2013, pp. 33-41, doi: 10.13189/ujer.2013.010201

[12] M. Y. Erdoğdu, "Parental Attitude and Teacher Behaviours in Predicting School Bullying," in Journal of Education and Training Studies, vol. 4(6), 2016, pp. 35-43, doi:10.11114/jets.v4i6.1459.

[13] A. Jan, \& S. Husain, Bullying in Elementary Schools: Its Causes and Effects on Students. Journal of Education and Practice, 6(19): 2015, pp. 43-56. http://files.eric.ed.gov/fulltext/EJ1079521.pdf

[14] S. E., Jones, A. S. R., Manstead, and A. G. Livingstone, "Bullying and Belonging: Teachers' Reports of School Aggression," in Frontline Learning Research, vol. 3, 2014, pp. 64-77. http://files.eric.ed.gov/fulltext/EJ1090834.pdf

[15] R. E. Slavin, Psychology Education. Boston: Pearson Education, Inc. 2006.
[16] Nevid, J. S. An Introduction to Psychology, Fourth Edition, International Edition. Canada: Wadsworth, Cengage Learning. 2013. P.513

[17] K., Craig, D., Bell, and A. Leschied, 2011. "Pre-service Teachers' Knowledge and Attitudes Regarding School-Based Bullying," in Canadian Journal of Education, vol. 34(2), 2011, pp. 21-33. http://files.eric.ed.gov/fulltext/EJ936744.pdf

[18] J. E. Omrod, Psikologi Pendidikan Membantu Siswa Tumbuh dan Berkembang. Terjemahan oleh Wahyu Indianti, dkk. 2008. Jakarta: Erlangga. 2008. p. 118.

[19] N. R. Carlson, Psychology: the Science of Behavior. Boston: Allyn and Bacon. 1990.

[20] Akbar, S. Revitalisasi Pendidikan Karakter di Sekolah Dasar. Pidato Pengukuhan Guru Besar dalam Bidang Ilmu Pendidikan Dasar pada Fakultas Ilmu Pendidikan (FIP) UM, Malang, Universitas Negeri Malang, 8 Juni. 2011.

[21] T. Lickona, Educating for Character: How Our Schools Can Teach Respect and Responsibility. New York: Bantam Books, 2009.

[22] G. Skaggs, and N. Bodenhorn, "Relationships Between Implementing Character Education, Student Behavior, and Student Achievement." in Journal of Advance Academics, vol. 18(1), 2006, pp. 82-114, http://files.eric.ed.gov/fulltext/EJ753972.pdf

[23] J. S. Beninga, M.W., Berkowitz, P. Kuehn, and K. Smith, "The Relationship of Character Education Implementation and Academic Achievement in Elementary Schools," in Journal of Research in Character Education, vol. 1(1), 2003, pp. 19-32. http://www.csufresno.edu/kremen/bonnercenter/documents/Character _Education.pdf

[24] A. Agboola, and K. C. Tsai, "Bring Character Education into Classroom," in Europan Journal of Educational Research, vol 1(2), 2012, pp. 163-170. http://files.eric.ed.gov/fulltext/EJ1086349.pdf 